\title{
Article \\ Growing Environment and Heat Treatment Effects on Intra- and Interspecific Pollination in Chile Pepper (Capsicum spp.)
}

\author{
Tsung Han Lin, Shih Wen Lin, Yen Wei Wang, Maarten van Zonneveld and Derek W. Barchenger*
}

\section{check for}

updates

Citation: Lin, T.H.; Lin, S.W.; Wang, Y.W.; van Zonneveld, M.; Barchenger, D.W. Growing Environment and Heat Treatment Effects on Intra- and Interspecific Pollination in Chile Pepper (Capsicum spp.). Agronomy 2021, 11, 1275. https://doi.org/ 10.3390/agronomy11071275

\section{Academic Editors: Theodore}

Radovich, Michael Kantar, Robert

E Paull and Francis Drummond

Received: 2 June 2021

Accepted: 21 June 2021

Published: 23 June 2021

Publisher's Note: MDPI stays neutral with regard to jurisdictional claims in published maps and institutional affiliations.

Copyright: (c) 2021 by the authors. Licensee MDPI, Basel, Switzerland. This article is an open access article distributed under the terms and conditions of the Creative Commons Attribution (CC BY) license (https:// creativecommons.org/licenses/by/ $4.0 /)$.
World Vegetable Center, Shanhua, Tainan 74151, Taiwan; Tsung-han.lin@worldveg.org (T.H.L.); susan.lin@worldveg.org (S.W.L.); vivian.wang@worldveg.org (Y.W.W.); maarten.vanzonneveld@worldveg.org (M.v.Z.)

* Correspondence: derek.barchenger@worldveg.org

\begin{abstract}
Heat tolerance is important for the sustainable production of many crops, including chile pepper. Tolerance to high temperature is complex and involves various component traits, with pollen viability being among the most important. in vitro pollen assays for heat tolerance have been widely used in chile pepper; however, associations between the pollen treatment and pollination have not been widely explored. The objectives of this study were to validate the utility of in vitro heat stress pollen characterization through in vivo pollination during summer and winter seasons and to evaluate the cross-compatibility among wild and domesticated species to initiate introgression population development. Seven entries of wild and domestic Capsicum species grown during the summer and winter seasons were used to evaluate pollination success rate. Pollen was either used directly or treated at $38^{\circ} \mathrm{C}$ for four hours before making reciprocal self- and cross-pollination among all the entries. Significant associations between in vitro pollen treatment and pollination success rate during summer and winter seasons were identified. Heat treatment was a greater contributor to variability than the growing environment, which validates previous reports on the usefulness of studying pollen in vitro in selection for heat tolerance. Accessions of the wild progenitor C. annuum var glabriusculum, PBC 1969 and PBC 1970, were identified as a potential heat-tolerant source for use in breeding and future research. This work provides a basis for future research in exploring additional heat tolerance components as well as for the development of phenotyping assays for pollen or other floral traits.
\end{abstract}

Keywords: crop wild relatives; cross-compatibility; heat tolerance; pollen viability

\section{Introduction}

Chile pepper (Capsicum annuum L.) is consumed worldwide, and global production was 5.1 million tons in 2018, with approximately 65\% of production occurring in Asia [1]. The primary limitations to improving the productivity and quality of chile pepper are abiotic and biotic stresses, many of which lack sources of host tolerance or resistance for breeding [2]. Maximum chile pepper yields occur when daily temperatures range between 18 and $32{ }^{\circ} \mathrm{C}$ during fruit set [3]. It can be anticipated that in many production regions it will become more difficult to grow chile pepper as temperatures increase beyond this optimal temperature range as a consequence of global climate change. In response to high temperatures, chile peppers abort reproductive organs (buds, flowers, and young fruits), resulting in a significant reduction in yield. Unlike other stresses, such as pests and diseases or short-term drought and flooding, it is difficult to manage the effects of heat stress in a farm setting, leaving genetic improvement as the best strategy to limit losses associated with high temperatures. However, breeding for heat tolerance is complex and requires the evaluation of numerous component traits.

Pollen is the most heat susceptible tissue in many crops [4,5], and without viable pollen, the fruit set is reduced or completely impeded. Selection for heat-tolerant plants can be achieved by monitoring fruit sets, but this method does not discriminate between 
the various flower traits involved (pollen viability, pollen activity, style exertion, stigma non-receptivity, arrested pollen tube growth, or other reasons). Furthermore, it requires measuring fruit set over an extended time and is sensitive to variations in temperature that could permit an otherwise heat-sensitive plant to set fruit.

Wild relatives of crop plants could contain genes related to high pollen viability under high temperatures, as demonstrated with tomato (Solanum lycopersicum) and its wild relatives [6]. The diversity contained among the wild Capsicum species represents a valuable genetic resource for crop improvement of chile pepper [7]. Given that many wild species of Capsicum have evolved in harsh environments, such as in seasonally dry tropical forests, with adverse climatic conditions and high disease pressure, they could express traits for tolerance to a wide range of stress factors [8]. However, in contrast to other Solanaceae crops, including tomato [9] and potato (S. tuberosum) [10], introgression breeding using wild species has been neglected in Capsicum [7]. Although the genetic diversity and variation within wild populations of Capsicum have been studied [11-15], phenotypic and genotypic information of wild Capsicum species remains limited $[8,16]$. Lack of phenotypic characterization is likely the major reason why wild relatives are not widely used for improving the chile pepper crop, followed by pre- or post-zygotic barriers to fertilization and linkage drag [17].

To use the traits of wild relatives in breeding programs, there is a need to understand the potential of these traits for improving the stress resilience of cultivated chile pepper. Wild relatives have been explored in some breeding programs with a major focus on characterizing phylogeny, genetic relatedness, morphology, and cross-compatibility as a basis for understanding interspecies compatibility and identifying barriers to hybridization, which are essential to the design of introgression breeding programs [16]. However, the direct use of multigenic traits derived from wild Capsicum species, which are morphologically divergent and not adapted to modern production systems, has not been successful. Difficult phenotyping, crossing barriers, and linkage drag were the major reasons for this failure.

Reddy and Kakani [17] developed a protocol to assess pollen germination and pollen tube length of chile pepper in vitro, which involved heat treating pollen to temperatures ranging from 15 to $50^{\circ} \mathrm{C}$ and incubating the pollen for $24 \mathrm{~h}$. The authors found that 30.7 and $31.2{ }^{\circ} \mathrm{C}$ were the optimal temperatures for pollen germination and maximum pollen tube length, respectively, and 41.8 and $40.4{ }^{\circ} \mathrm{C}$, respectively, were the critical temperatures to induce stress. To increase throughput, Heidmann et al. [18] utilized impedance flow cytometry (IFC) to evaluate the pollen of sweet pepper for tolerance to high temperatures. They found a significant reduction in pollen viability at temperatures greater than $48{ }^{\circ} \mathrm{C}$ and a significant positive association was found between pollen viability based on fluorescein diacetate staining and pollen activity using IFC. However, the association between in vitro pollen treatment and evaluation with in vivo fruit setting in chile pepper has not yet been determined. Similarly, plant growing environment and laboratory-based pollen heat treatment have not been compared for chile pepper. Furthermore, it is known that the cross-compatibility among wild and domesticated Capsicum accessions has yet to be resolved [16]. Therefore, the objectives of this study were to (i) validate the utility of in vitro heat stress pollen characterization through in vivo cross- and self-pollination among heattolerant Capsicum accessions during high temperature and optimal growing seasons and (ii) to evaluate the cross-compatibility among wild and domesticated species to initiate introgression population development, with the overall aim of supporting future research by plant breeders in this important area.

\section{Materials and Methods}

For this experiment, seven wild and domesticated Capsicum entries including two members of the domesticated C. annuum (AVPP9905 and AVPP9823), two members of the wild progenitor C. annuum var glabriusculum (PBC 1969 and PBC 1970), two members of the wild species C. chacoense (VI012900 and VI029126), and one C. galapagoense accession (NMCA50026) were evaluated. All experiments were conducted at the World 
Vegetable Center, Shanhua, Tainan, Taiwan (lat. 23.1 ${ }^{\circ}$ N; long. $120.3^{\circ}$ E; elevation $12 \mathrm{~m}$ ). Prior to sowing, all seed was treated with trisodium phosphate (TSP) and hydrochloric acid $(\mathrm{HCl})$ following the methods of Kenyon et al. [19]. Seeds were sown into 72-cell plastic trays (Wen-kai Plastic, Nantou, Taiwan) of sterilized King Root substrate V008 (Dayi Agritech, Pingtung, Taiwan) and placed in a climate-controlled greenhouse for germination at $28 \pm 3{ }^{\circ} \mathrm{C}$ with a $12 \mathrm{~h}$ photoperiod and $95 \%$ relative humidity. Plants were irrigated twice daily and after germination, the seedlings were fertilized with Nitrophoska (Incitec Pivot Fertilisers, Victoria, Australia). At the 4-6 true leaf stage, the seedlings were transplanted into field screen houses covered in 32 mesh nylon nets (Hong Yung Plastic Weaving, Taichung, Taiwan) in double rows at a space of $45 \mathrm{~cm} \times 90 \mathrm{~cm}$. Rows were covered with a black polyethylene mulch (Her Mei Plastic, Tainan, Taiwan) and staked with $13 \mathrm{~mm} \times 130 \mathrm{~cm}$ fiber-reinforced plastic stakes (Goodwill Fiberglass, Taipei, Taiwan). Plants were maintained as uniformly as possible using best management practices [20]. Regular scouting was carried out for pests and disease and appropriate pesticides were applied as required.

This experiment was conducted during two seasons-the summer season (April to August) and the winter season (October to February). The temperature and relative humidity inside the field net house were recorded every $15 \mathrm{~min}$ throughout the experimental period using a HOBO data logger (Pro v2 U23; Onset Computer Corporation, Bourne, MA, USA). The HOBO data logger was mounted at approximately the height of a mature chile pepper plant ( 1 $\mathrm{m}$ above the ground) and to eliminate direct exposure by sunlight and rain, it was mounted inside a plastic container, which was open at the bottom.

Once the plants reached the reproductive stage, flowers at the ST3 to ST5 stage, as described by Lin et al. [21], were selected for experimentation. The flowers were either heat treated in vitro (heat treatment) or used directly (control) for self-pollination of among plants the same accession or cross-pollination between accessions.

For in vitro heat treatment, the flowers were placed in Petri dishes and exposed to $38^{\circ} \mathrm{C}$ temperatures inside an incubator (JBL-30, Prosperous Instruments, Chaiyi, Taiwan) in darkness for four hours. Reciprocal hybridizations were made using all parental lines for both heat-treated and untreated flowers as well as hand self-pollinations. For each cross- or self-pollination combination, five individual pollinations were made, and each was labeled with tags (Hang Kuang, Tainan, Taiwan). At the end of the season, all labels were collected, and the percentage of pollination success was calculated.

Pollination was considered a failure if either the female flower did not result in fruit or if the resulting fruit was parthenocarpic and did not produce any seed, while successful pollinations were those in which a fruit reached maturity and produced seed. The experiment followed a split-plot design, with four replications each consisting of six plants, with the split being heat treatment. For analysis, 1 was added to all of the success rates so that they ranged from 1 to $101 \%$, and then the $\log _{10}$-transformed, crosscompatibility success rate data for the growing season, treatment, accession, and species were analyzed using analysis of variance $(\alpha=0.05)$ and correlations among data averaged across growing season and heat treatment using Pearson's correlation coefficient $(\alpha=0.05)$ in R-3.6.3 [22].

\section{Results}

During the summer season, the monthly maximum temperature ranged from 41 to $44^{\circ} \mathrm{C}$ and the average temperature was $28.6^{\circ} \mathrm{C}$, with the hottest temperatures typically occurring during the reproductive stage of the plants. During the winter season, the average temperature was $22.8^{\circ} \mathrm{C}$, with the monthly maximum temperature ranging from 36 to $44{ }^{\circ} \mathrm{C}$, with average cooler temperatures occurring during the reproductive growth stage (Table 1). Relative humidity was generally stable during the experimental period with monthly averages ranging from 74 to $86 \%$. During the summer season (April to August), the C. galapagoensis accession, NMCA50026, did not produce flowers, and the majority of the plants of this accession did not survive (Figure 1). 
Table 1. Monthly temperature and relative humidity $(\mathrm{RH})$ values, recorded during the two seasons of the experiment in Shanhua, Tainan, Taiwan.

\begin{tabular}{|c|c|c|c|c|c|c|c|c|}
\hline Season & Month & $\begin{array}{l}\text { Plant } \\
\text { Growth } \\
\text { Stage }\end{array}$ & $\begin{array}{l}\text { Mean Tem- } \\
\text { perature } \\
\left({ }^{\circ} \mathrm{C}\right)\end{array}$ & $\begin{array}{l}\text { Maximum } \\
\text { Temperature } \\
\left({ }^{\circ} \mathrm{C}\right)\end{array}$ & $\begin{array}{c}\text { Minimum } \\
\text { Temperature } \\
\left.{ }^{\circ} \mathrm{C}\right)\end{array}$ & $\begin{array}{c}\text { Mean RH } \\
(\%)^{1}\end{array}$ & $\begin{array}{c}\text { Maximum } \\
\text { RH (\%) }\end{array}$ & $\begin{array}{c}\text { Minimum } \\
\text { RH (\%) }\end{array}$ \\
\hline \multirow[t]{5}{*}{ Summer } & 4 & Vegetative & 26.8 & 41 & 17.5 & 77.7 & 100 & 33.8 \\
\hline & 5 & Vegetative & 27.7 & 43.8 & 19.8 & 83.2 & 100 & 38.7 \\
\hline & 6 & Reproductive & 30 & 42.7 & 22.9 & 81.6 & 100 & 35.1 \\
\hline & 7 & Reproductive & 29.5 & 43.9 & 24.1 & 86.1 & 100 & 42.4 \\
\hline & 8 & Reproductive & 28.7 & 42.9 & 23.9 & 90.4 & 100 & 42.3 \\
\hline \multirow[t]{5}{*}{ Winter } & 10 & Vegetative & 27.5 & 44.3 & 19.4 & 70.2 & 100 & 30.3 \\
\hline & 11 & Vegetative & 24.8 & 41.4 & 14.4 & 74 & 100 & 29.4 \\
\hline & 12 & Reproductive & 20.6 & 36.9 & 9.7 & 81.4 & 100 & 30 \\
\hline & 1 & Reproductive & 19.9 & 38.3 & 5.4 & 80.5 & 100 & 24.8 \\
\hline & 2 & Reproductive & 20.9 & 39.2 & 7.9 & 76.6 & 100 & 28.6 \\
\hline
\end{tabular}

Treatment

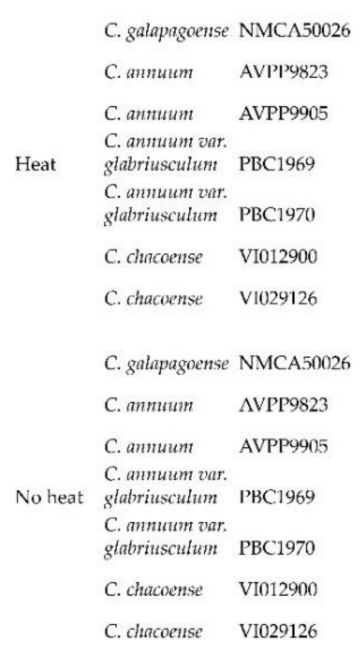

Spring season

NMCA50026 AVPP9823 AVPP9905 PBC1969 PBC1970 VI012900 VI029126
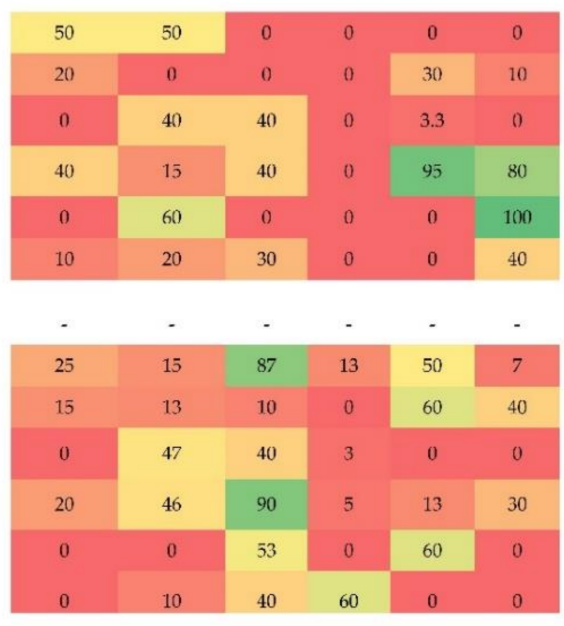

Winter season

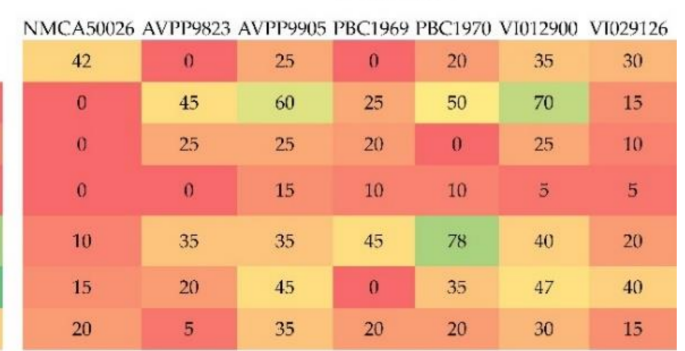

\begin{tabular}{|c|c|c|c|c|c|c|}
\hline 54 & 40 & 15 & 40 & 43 & 39 & 40 \\
\hline 64 & 58 & 51 & 68 & 80 & 69 & 63 \\
\hline 10 & 38 & 75 & 55 & 65 & 20 & 35 \\
\hline 8 & 75 & 95 & 72 & 40 & 20 & 34 \\
\hline 54 & 90 & 95 & 90 & 95 & 80 & 80 \\
\hline 32 & 95 & 90 & 80 & 80 & 75 & 80 \\
\hline 41 & 85 & 90 & 87 & 66 & 70 & 90 \\
\hline
\end{tabular}

Figure 1. Heat map of the intra- and interspecific cross- and self-pollination success rates for the four Capsicum species evaluated during the summer and winter seasons under no-heat and in vitro heat treatment at $38^{\circ} \mathrm{C}$ for $4 \mathrm{~h}$. The accessions are listed on the $y$-axis when used as a female parent and on the top of the figure when used as a male parent. Values within each cell are nontransformed percentages, although data were $\log _{10}$ transformed for analysis.

The two-way interaction of season by heat treatment significantly contributed to the variability observed for pollination success rate $(p \leq 0.001$; Table 2$)$. The main effect of pollen heat treatment $($ F-value $=90.2)$ was the greatest single contributor to the variability observed, followed by the growing season (F-value $=11.8$ ) (Figure 1). The overall highest pollination success was achieved during the winter season under no-heat treatment (Figure 1). The self- or cross-pollination success rate of the heat-treated pollen during the winter season was not significantly different from the success rate using the heat- or untreated pollen during the summer season. 
Table 2. Analysis of variance of the $\log _{10}$-transformed pollination success rate of four Capsicum species under heat and no-heat treatment during winter and summer seasons.

\begin{tabular}{ccccc}
\hline Factor & DF $^{\mathbf{1}}$ & Mean Squares & F-Value & $p$-Value \\
\hline Season & 1 & 6.2 & 11.8 & 0.001 \\
Treatment & 1 & 46.9 & 90.2 & $<0.001$ \\
Female accession & 6 & 4.1 & 7.1 & $<0.001$ \\
Male accession & 6 & 1.7 & 2.9 & 0.009 \\
Female species & 3 & 0.5 & 0.7 & 0.559 \\
Male species & 3 & 2.6 & 4.3 & 0.006 \\
Season $\times$ treatment & 1 & 4.3 & 8.3 & 0.004 \\
Female $\times$ male & 36 & 0.8 & 1.3 & 0.106 \\
Female sp. $\times$ male sp. & 9 & 1.7 & 2.7 & 0.005 \\
Replication(treatment) & 6 & 3.7 & 9.1 & $<0.001$ \\
Residuals & 406 & 0.4 & & \\
\hline
\end{tabular}

${ }^{1}$ Degree of freedom for numerator.

The main effects of male parent and female parent used for pollination significantly affected the success rate ( $p \leq 0.01$ and $p \leq 0.001$, respectively), with the selection of female parent being the largest contributor to success rate $(\mathrm{F}$-value $=7.0)$ (Table 2$)$. The highest overall success rate was achieved when AVPP9905 (C. annuum) and PBC 1969 (C. annuum var. glabriusculum) were used as the male parents, while NMCA50024 (C. galapagoense) had the overall lowest success rate as the male parent (Figure 1). When used as the female parent, PBC 1970 (C. annuum var. glabriusculum) had the overall highest success rate, while PBC 1969 had the lowest (Figure 1).

The two-way interaction of selection of species used as the male or female for crossor self-pollination significantly contributed to the variability observed for the success rate $(p<0.05)$ (Table 2). The highest pollination success rate was achieved when members of the domesticated $C$. annuum species were used as both the male and female parent, followed by the wild progenitor $C$. annuum var. glabriusculum (Figure 1). The lowest pollination success rate was observed when a member of the wild C. galapagoense was used as the female parent and when a member of the wild progenitor C. annuum var. glabriusculum was used as the male parent (Figure 1).

The smallest difference in pollination success rate between summer $(90 \%)$ and winter season $(90 \%)$ was observed when members of the wild progenitor $C$. annuum var. glabriusculum PBC 1969 was used as the male parent and PBC 1970 was used as the female parent under the no-heat treatment (Figure 1). When AVPP9823 was used as the male parent, and VI012900 was the female parent, the greatest difference in pollination success rate was observed between the winter $(95 \%)$ and the summer $(0 \%)$ season (Figure 1$)$. The greatest difference in pollination success rate between heat and no-heat treatment was found when VI012900 was the female parent, and PBC 1969 was the male parent, with 0 and $80 \%$ pollination success, respectively. The smallest difference between heat and no-heat treatment was found when VI012900 was used as the male parent, and AVPP9823 was the female parent, with 69 and $70 \%$ pollination success, respectively.

Pollination success rate during the winter season was positively correlated with both heat $(r=0.77)$ and no-heat-treated pollen success rate $(r=0.86)$ but not with pollen success rate during the summer season $(r=0.26)$ (Table 3$)$. The correlation between pollen success rate during the summer season with both heat and no-heat-treated pollen success rate was lower ( $r=0.46$ and 0.36 , respectively) but still significant at $\alpha=0.05$ (Table 3 ). 
Table 3. Pearson's correlation coefficient (lower half) and $p$-values (upper half) for $\log _{10}$-transformed pollination success rates under different treatments and seasons.

\begin{tabular}{ccccc}
\hline & $\begin{array}{c}\text { Summer } \\
\text { Season }\end{array}$ & $\begin{array}{c}\text { Winter } \\
\text { Season }\end{array}$ & $\begin{array}{c}\text { Heat } \\
\text { Treatment }\end{array}$ & $\begin{array}{c}\text { No Heat } \\
\text { Treatment }\end{array}$ \\
\hline Summer season & & 0.122 & 0.005 & 0.031 \\
Winter season & 0.26 & & $<0.001$ & $<0.001$ \\
Heat treatment & 0.46 & 0.77 & & 0.005 \\
No-heat treatment & 0.36 & 0.86 & 0.39 & \\
\hline
\end{tabular}

\section{Discussion}

During this experiment, the plants were exposed to external temperatures that exceeded the previously reported maximum threshold [23-28] to induce heat stress during the summer season. While temperatures were high, especially during the vegetative stage of the experiment, the average temperatures were more optimal during the winter season, which is reflected in the generally higher pollination success rates during the winter season. During both seasons, the temperature and $\mathrm{RH}$ were greater than might be expected. This is likely due to the use of a mesh net house to prevent pollinating insects from influencing the pollination experiment. The $\mathrm{RH}$ throughout the experimental period was relatively stable, also likely due to the plants being grown in the mesh net house, which allows for the seasonal variability observed for pollination success rate to be explained more accurately by temperature rather than $\mathrm{RH}$.

Both short-term high and long-term mildly elevated day and night temperatures are known to negatively affect pollen development in many crops [29], including chile pepper [23]. Although pollen development was not studied, the pollination success rate almost always lowers during the summer season, as compared to the winter season. In response to high temperatures, plants have various mechanisms to maintain cellular homeostasis to cope with heat stress, which has been widely studied in the vegetative stages of different plant species [30]; however, little is known about these mechanisms in developing pollen. The starch and sugar content in maturing pollen grains has been shown to be affected by long-term, elevated temperature [23,27-31]. Furthermore, a significant relationship between in vitro pollen germination rate and pollen tube length after exposure to long periods of high temperatures with whole-plant thermotolerance for chile pepper [32], as well as other crops such as soybean (Glycine max) [33], has been found. Therefore, using pollen traits as an indicator of heat tolerance has been reported to be an effective technique, and in vitro assays to assess pollen response to heat stress have been developed $[17,18,21]$. While it is known that pollen viability, pollen tube germination, and pollen tube length are reduced under heat stress [17,23,24], it has not been empirically shown if this results in an actual reduction in pollination. This experiment was conducted to determine the relationships between stressful growing environments and heat treatment with self- and cross-pollination. Using a modified in vitro heat treatment assay developed by Reddy and Kakani [17], differences in pollination success among accessions were found. This variability indicates that the accessions used in this study have different levels of heat tolerance. As expected, pollination success was lower during the summer season, which was hotter than the winter season.

The pollination success rate using in vitro heat treatment was significantly correlated with the pollination success rate during the summer season. Similarly, the pollination success rate during the winter season was significantly correlated with the pollination success rate under no in vitro heat treatment. This indicates that in vitro pollen heat treatment could be an effective strategy to select for heat tolerant accessions. In addition, in vitro heat treatment pollination success rate was also significantly correlated with pollination success rate during the winter season, which seems contradictory but could be explained by certain accessions having generally higher or lower pollination success rates, despite the growing season or heat treatment. For example, AVPP9905, a previously reported heat-tolerant line [34], was among the samples with the highest average pollination success 
rates when used as a male parent during the summer season (26\%), the winter season (54\%), under in vitro heat treatment (33\%), and under no treatment (47\%), while AVPP9823 was among the samples with the lowest average pollination success rates during the summer season $(15 \%)$, the winter season $(44 \%)$, under in vitro heat treatment $(20 \%)$, and under no treatment $(39 \%)$.

Given that many wild Capsicum species originate from harsh environments, including high temperatures and water-deficit stress [8], it is hypothesized that they could serve as sources of tolerance to abiotic stress [16]. Reddy and Kakani [17] found an accession of the wild species $C$. chacoense that had intermediate heat tolerance, while accessions from domesticated species were either highly heat tolerant or sensitive. Typically, the accessions of domesticated species had higher pollination success rates than accessions of the wild species during the cool season. However, during the hot season, the wild accession PBC 1969 had the highest overall pollination success rate. With the exception of the C. galapagoense accession NMCA50026, pollination success for the no-heat treatment was very similar for both wild and domesticated accessions. It is possible that the higher pollination success rates during the cool season for accessions of the domesticated C. annuum was due to larger flower size, making hybridizations easier and by default more successful.

Another factor affecting pollination success rate is prezygotic barriers to fertilization among the different species of Capsicum. The intra- and interspecific pollination success rates of wild and domesticated Capsicum species have been previously studied [16,24-33,35-38]. Under no-heat treatment during the winter season, the cross-pollination success rates were similar to those of Parry et al. [16], with higher reciprocal pollination success for accessions from the same species than success rates between species. Although pollination success among members of the domesticated C. annuum and the wild C. annuum var. glabriusculum and C. chacoense was in line with other reports [16,36-38], typically, pollination success using the C. galapagoense accession in either direction was lower than for other species, which contradicts the findings of Pickersgill [37], who found relatively high success rates between members of C. galapagoense and C. annuum. Recently, evidence for the misidentification of members of $C$. galapagoense has been reported, which could be the reason for differences in interspecific pollination success [16].

The response of chile pepper to high temperatures at the vegetative (generally seedling) [34,39-43] and reproductive [23,24,26,44,45] stages during the growing season has been previously explored. In recent years, researchers have characterized differentially expressed genes in response to high-temperature stress in chile pepper [34,39-42]. In vitro bioassays have been developed to effectively screen chile pepper accessions for heat tolerance $[17,18,21]$. This study is the first report validating the use of in vitro heat treatment assays and pollination success in vivo in chile pepper. We found that the negative effects of high temperatures on floral tissues, particularly pollen, indeed result in a reduction in pollination success. The body of literature on inducing heat stress and evaluating the pollination cross- and self-pollination success rates is extremely limited. It is critically important to validate in vitro bioassays using in vivo experiments that closely mimic actual conditions, which this study does.

\section{Conclusions}

Breeding for heat tolerance in fruiting crops such as chile pepper is becoming increasingly important. In order to be effective in the selection, appropriate bioassays must be developed and validated for accuracy and representative of field conditions. In this study, significant associations between in vitro pollen treatment and pollination success rate during summer and winter seasons were identified, and it was found that heat treatment was a greater contributor to variability than the growing environment, which validates previous reports on the usefulness of studying pollen in vitro in selection for heat tolerance. PBC 1969 and PBC 1970, accessions of the wild progenitor C. annuum var glabriusculum, were identified as potential heat-tolerant sources for use in breeding and future research. This work is among the first to explore the relationship of heat treatment with high-temperature 
stress in terms of actual pollination success in chile pepper. The findings presented here provide a basis for future research in exploring additional heat tolerance components in chile pepper and other crops and for the development of phenotyping assays for pollen or other floral traits.

Author Contributions: Conceptualization, M.v.Z. and D.W.B.; funding acquisition, M.v.Z. and D.W.B.; investigation, T.H.L.; project administration, S.W.L. and Y.W.W. writing-original draft preparation, T.H.L. All authors have read and agreed to the published version of the manuscript.

Funding: Funding for this research was provided by the Ministry of Science and Technology of Taiwan (Project ID: 107-2311-B-125-001-MY3) and long-term strategic donors to the World Vegetable Center, Taiwan; US Agency for International Development (USAID); UK aid from the UK government; Australian Centre for International Agricultural Research (ACIAR), Germany, Thailand, Philippines, Korea, and Japan.

Institutional Review Board Statement: Not applicable.

Informed Consent Statement: Not applicable.

Data Availability Statement: All data collected during this experiment were deposited in the World Vegetable Center repository, HARVEST (https:/ / worldveg.org/harvest3/, accessed on 1 June 2021) and are available to the public.

Acknowledgments: We are grateful to Paul W. Bosland of the Chile Pepper Institute at New Mexico State University for providing accessions of several of the wild Capsicum species used in this experiment. We also thank Didit Ledesma for providing guidance in designing the experiment.

Conflicts of Interest: The authors declare no conflict of interest.

\section{References}

1. Food and Agriculture Organization of the United Nations. FAOSTAT Statistical Database. 2019. Available online: http: //www.fao.org/faostat/en/\#data/QC (accessed on 22 January 2020).

2. Barchenger, D.W.; Naresh, P.; Kumar, S. The Capsicum Genome; Ramchiary, N., Kole, C., Eds.; Springer Nature Switzerland AG: Cham, Switzerland, 2019; Chapter 2; pp. 9-23.

3. Sanders, D.C.; Kirk, H.J.; van der Brink, C. Growing Degree Days in North Carolina; North Carolina Agricultural Extension Service: Sparta, NC, USA, 1980.

4. Hedhly, A.; Hormaza, J.I.; Herrero, M. Global warming and sexual plant reproduction. Trends Plant Sci. 2009, 14, 30-36. [CrossRef]

5. Giorno, F; Wolters-Arts, M.; Mariani, C.; Rieu, I. Ensuring reproduction at high temperatures: The heat stress response during anther and pollen development. Plants 2013, 2, 489-506. [CrossRef] [PubMed]

6. Driedonks, N.; Wolters-Arts, M.; Huber, H.; de Boer, G.J.; Vriezen, W.; Mariani, C.; Rieu, I. Exploring the natural variation for reproductive thermotolerance in wild tomato species. Euphytica 2018, 214, 67. [CrossRef]

7. Barchenger, D.W.; Bosland, P.W. Cultivated Wild Relatives of North America; Greene, S., Williams, K., Khoury, C.K., Kantar, M.B., Marek, L., Eds.; Springer Nature Switzerland AG: Cham, Switerzland, 2019; Volume 2, Chapter 7; pp. 225-242.

8. Khoury, C.K.; Carver, D.; Barchenger, D.W.; Barboza, G.; van Zonneveld, M.; Jarret, R.; Bohs, L.; Kantar, M.; Uchanski, M.; Mercer, K.; et al. Modeled distributions and conservation status of the wild relatives of chile peppers (Capsicum L.). Divers. Distrib. 2020, 26, 209-225. [CrossRef]

9. Lin, T.; Zhu, G.; Zhang, J.; Xu, X.; Yu, Q.; Zheng, Z.; Zhang, Z.; Lun, Y.; Li, S.; Wang, X.; et al. Genomic analyses provide insights into the history of tomato breeding. Nat. Genet. 2014, 46, 1220-1226. [CrossRef] [PubMed]

10. Hirsch, C.N.; Hirsch, C.D.; Felcher, K.; Coombs, J.; Zarka, D.; van Deynze, A.; de Jong, W.; Veilleux, R.E.; Jansky, S.; Bethke, P.; et al. Retrospective view of North American potato (Solanum tuberosum L.) breeding in the 20th and 21st centuries. G3 Genes Genom Genet. 2013, 3, 1003-1013. [CrossRef]

11. Aguilar Meléndez, A.; Morrell, P.L.; Roose, M.L.; Kim, S.C. Genetic diversity and structure in semiwild and domesticated chiles (Capsicum annuum; Solanaceae) from Mexico. Am. J. Bot. 2009, 96, 1190-1202. [CrossRef] [PubMed]

12. Carrizo García, C.; Barfuss, M.H.J.; Sehr, E.M.; Barboza, G.E.; Samuel, R.; Moscone, E.A.; Ehrendorfer, F. Phylogenetic relationships, diversification and expansion of chili peppers (Capsicum, Solanaceae). Ann. Bot. 2016, 118, 35-51. [CrossRef]

13. Cheng, J.; Qin, C.; Tang, X.; Zhou, H.; Hu, Y.; Zhao, Z.; Cui, J.; Li, B.; Wu, Z.; Yu, J.; et al. Development of a SNP array and its application to genetic mapping and diversity assessment in pepper (Capsicum spp.). Sci. Rep. 2016, 6, 33293. [CrossRef]

14. Oyama, K.; Hernández-Verdugo, S.; Sánchez, C.; González-Rodríguez, A.; Sánchez-Peña, P.; Garzón-Tiznado, J.A.; Casas, A. Genetic structure of wild and domesticated populations of Capsicum annuиm (Solanaceae) from northwestern Mexico analyzed by RAPDs. Genet. Resour. Crop Evol. 2006, 53, 553-562. [CrossRef] 
15. Votava, E.J.; Nabhan, G.P.; Bosland, P.W. Genetic diversity and similarity revealed via molecular analysis among and within an in situ population and ex situ accessions of chiltepín (Capsicum annuum var. glabriusculum). Conserv. Genet. 2002, 3, 123-129. [CrossRef]

16. Parry, C.; Wang, Y.W.; Lin, S.W.; Barchenger, D.W. Reproductive compatibility in Capsicum is not necessarily reflected in genetic or phenotypic similarity between species complexes. PLoS ONE 2021, 16, e0243689. [CrossRef]

17. Reddy, K.R.; Kakani, V.G. Screening Capsicum species of different origins for high temperature tolerance by in vitro pollen germination and pollen tube length. Sci. Hort. 2007, 112, 130-135. [CrossRef]

18. Heidmann, I.; Schade-Kampmann, G.; Lambalk, J.; Ottiger, M.; Di Berardino, M. Impedance flow cytometry: A novel technique in pollen analysis. PLoS ONE 2016, 11, e0165531. [CrossRef] [PubMed]

19. Kenyon, L.; Hanson, P.; Kumar, S.; Shih, S.L.; Hsieh, M.H.; Chen, H.Y.; Lu, S.F.; Wang, Y.Y.; Lin, S.W.; Cheng, Y.H. Treatment for Cleaning Small Seed lots of Tomato and Pepper Seeds of Surface Contamination with Viroids. The World Vegetable Center. 2017. Available online: https://worldveg.tind.io/record/74053?ln=en (accessed on 19 December 2020).

20. Berke, T.; Black, L.L.; Talekar, N.S.; Wang, J.F.; Gniffke, P.; Green, S.K.; Wang, T.C.; Morris, R. Suggested Cultural Practices for Chili Pepper; World Vegetable Center: Tainan, Taiwan, 2005.

21. Lin, S.W.; Lin, T.H.; Wang, Y.W.; Barchenger, D.W. High throughput pollen phenotyping using impedance flow cytometry for heat tolerance selection in pepper (Capsicum sp.). HortScience 2020, 55, S156.

22. R Core Team. R: A Language and Environment for Statistical Computing; R Core Team: Vienna, Austria, 2020. Available online: https://www.R-project.org/ (accessed on 17 February 2021).

23. Aloni, B.; Peet, M.M.; Pharr, M.; Karni, L. The effect of high temperature and high atmospheric CO2 on carbohydrate changes in bell pepper (Capsicum annuum) pollen in relation to its germination. Physiol. Plant. 2001, 112, 505-512. [CrossRef] [PubMed]

24. Erickson, A.N.; Markhart, A.H. Flower developmental stage and organ sensitivity of bell pepper (Capsicum annuum L.) to elevated temperature. Plant Cell Environ. 2002, 25, 123-130. [CrossRef]

25. Guo, M.; Yin, Y.X.; Ji, J.J.; Ma, B.P.; Lu, M.H.; Gong, Z.H. Cloning and expression analysis of heat-shock transcription factor gene CaHsfA1 from pepper (Capsicum annuum L.). Genetic. Mol. Res. 2014, 13, 1865-1875. [CrossRef]

26. Polowick, P.L.; Sawhney, V.K. Temperature effects on male fertility and flower and fruit development in Capsicum annuum L. Sci. Hort. 1985, 25, 117-127. [CrossRef]

27. Pressman, E.; Peet, M.M.; Pharr, D.M. The effect of heat stress on tomato pollen characteristics is associated with changes in carbohydrates concentration in developing anthers. Ann. Bot. 2002, 90, 631-636. [CrossRef] [PubMed]

28. Wubs, A.M.; Heuvelink, E.; Marcelis, L.F.M. Abortion of reproductive organs in sweet pepper (Capsicum annuum L.): A review. J. Hortic. Sci. Biotech. 2009, 84, 467-475. [CrossRef]

29. Müller, F.; Rieu, I. Acclimation to high temperature during pollen development. Plant Reproduct. 2016, 29, 107-118. [CrossRef] [PubMed]

30. Kotak, S.; Larkindale, J.; Lee, U.; von Koskull-Doring, P.; Vierling, E.; Scharf, K.D. Complexity of the heat stress response in plants Curr. Opin. Plant Biol. 2007, 10, 310-316. [CrossRef]

31. Firon, N.; Shaked, R.; Preet, M.M.; Pharr, D.M.; Zamski, E.; Rosenfeld, K.; Althan, L.; Pressman, E. Pollen grains of heat tolerant tomato cultivars retain higher carbohydrate concentration under heat stress conditions. Sci. Hortic. 2006, 109, 212-217. [CrossRef]

32. Gajanayake, B.; Trader, B.W.; Raja Reddy, K.; Harkess, R.L. Screening ornamental pepper cultivars for temperature tolerance using pollen and physiological parameters. HortScience 2011, 46, 878-884. [CrossRef]

33. Salem, M.A.; Kakani, V.G.; Koti, S.; Reddy, K.R. Pollen-based screening of soybean genotypes for high temperatures. Crop Sci. 2007, 47, 219-231. [CrossRef]

34. Usman, M.G.; Radii, M.Y.; Ismail, M.R.; Malek, M.A.; Latif, M.A. Expression of target gene Hsp70 and membrane stability heat tolernace in chili pepper. J. Am. Soc. Hortic. Sci. 2015, 140, 144-150. [CrossRef]

35. Costa, L.V.; Lopes, R.; Lopes, M.T.G.; de Figueiredo, A.F.; Barros, W.S.; Alves, R.R.M. Cross compatibility of domesticated hot pepper and cultivated sweet pepper. Crop Breed. Appl. Biotechnol. 2009, 9, 37-44. [CrossRef]

36. da Silva Montero, C.E.; Santana Pereira, T.N.; de Campos, K.P. Reproductive characterization of interspecific hybrids among Capsicum species. Crop Breed. Appl. Biotechnol. 2011, 11, 3. [CrossRef]

37. Pickersgill, B. Relationships between weedy and cultivated forms in some species of chili peppers (genus Capsicum). Evolution 1971, 25, 683-691. [CrossRef]

38. Tong, N.; Bosland, P.W. Capsicum tovarii, a new member of the Capsicum baccatum complex. Euphytica 1999, 109, 71-77. [CrossRef]

39. Li, T.; Xu, X.; Li, Y.; Wang, H.; Li, Z.; Li, Z. Comparative transcriptome analysis reveals differential transcription in heat-susceptible and heat-tolerant pepper (Capsicum annum L.) cultivars under heat stress. J. Plant Biol. 2015, 58, 411-424. [CrossRef]

40. Zhai, Y.; Guo, M.; Wang, H.; Lu, J.; Liu, J.; Zhang, C.; Gong, Z.; Lu, M. Autophagy, a conserved mechanism for protein degradation, responds to heat, and other abiotic stresses in Capsicum annuum L. Front. Plant Sci. 2016, 7, 131. [CrossRef]

41. Feng, X.H.; Zhang, H.X.; Ali, M.; Gai, W.X.; Cheng, G.X.; Yu, Q.H.; Yang, S.B.; Li, X.X.; Gong, Z.H. A small heat shock protein CaHsp25.9 positively regulates heat, salt, and drought stress tolerance in pepper (Capsicum annuum L.). Plant Physiol. Biochem. 2019, 142, 151-162. [CrossRef] [PubMed]

42. Ali, M.; Muhammad, I.; Haq, S.U.; Alam, M.; Khattak, A.M.; Akhtar, K.; Ullah, H.; Khan, A.; Lu, G.; Gong, Z.H. The CaChiVI2 gene of Capsicum annuum L. confers resistance against heat stress and infection of Phytophthora capsici. Front. Plant Sci. 2020, 11, 219. [CrossRef] [PubMed] 
43. Rajametov, S.; Yang, E.Y.; Cho, M.C.; Chae, S.Y.; Jeong, H.B. Morpho-physiological pesponse to heat stress during seedling stage and interrelation with agronomical traits in pepper (Capsicum annuum L.) cultivars differing in heat tolerance. Res. Sq. 2021. [CrossRef]

44. Usman, I.S.; Mamat, A.S.; Syed Mohd, H.S.Z.; Aishan, H.S.; Anuar, R.A. The non-impairment of pollination and fertilization in the abscission of chilli (Capsicum annuum L. Var. Kulai) flowers under high temperature and humid conditions. Sci. Hortic. 1999, 79, 1-11. [CrossRef]

45. Motamedi, M.; Haghighi, M.; Goli, A. Physiological changes of sweet and hot peppers in vegetative and reproductive growth stages treated by $\mathrm{Ca}$ and $\mathrm{H}_{2} \mathrm{O}_{2}$ under unforeseen heat stresses. Sci. Hortic. 2018, 249, 306-313. [CrossRef] 